\title{
Gendered small-scale crops and power dynamics: A case of uninga (sesame) production amongst the Ndau of south-eastern Zimbabwe
}

\begin{tabular}{|c|c|}
\hline \multicolumn{2}{|c|}{$\begin{array}{l}\text { Authors: } \\
\text { Macloud Sipeyiye } \mathrm{e}^{1,2} \text { () } \\
\text { Tenson Muyambo }^{3} \text { (] }\end{array}$} \\
\hline $\begin{array}{l}\text { Affiliations: } \\
\text { 'Department } \\
\text { Studies, Facul } \\
\text { Midlands Stat } \\
\text { Zvishavane, Zi }\end{array}$ & $\begin{array}{l}\text { of Religious } \\
\text { ty of Arts, } \\
\text { e University, } \\
\text { mbabwe }\end{array}$ \\
\hline \multicolumn{2}{|c|}{$\begin{array}{l}{ }^{2} \text { Research Institute for } \\
\text { Theology and Religion (RITR), } \\
\text { University of South Africa, } \\
\text { Pretoria, South Africa }\end{array}$} \\
\hline \multicolumn{2}{|c|}{$\begin{array}{l}\text { Development, School of } \\
\text { Education and Culture, G } \\
\text { Zimbabwe University, } \\
\text { Masvingo, Zimbabwe }\end{array}$} \\
\hline \multicolumn{2}{|c|}{$\begin{array}{l}\text { Corresponding author: } \\
\text { Macloud Sipeyiye, } \\
\text { macloudsipeyiye5@gmail.com }\end{array}$} \\
\hline $\begin{array}{l}\text { Dates: } \\
\text { Received: } 07 \\
\text { Accepted: } 20 \\
\text { Published: } 30\end{array}$ & $\begin{array}{l}\text { Apr. } 2021 \\
\text { May } 2021 \\
\text { Nov. } 2021\end{array}$ \\
\hline \multicolumn{2}{|c|}{$\begin{array}{l}\text { How to cite this article: } \\
\text { Sipeyiye, M. \& Muyambo, T., } \\
\text { 2021, 'Gendered small-scale } \\
\text { crops and power dynamics: } \\
\text { A case of uninga (sesame) } \\
\text { production amongst the } \\
\text { Ndau of south-eastern } \\
\text { Zimbabwe', HTS Teologiese } \\
\text { Studies/Theological Studies } \\
77(2), \text { a6661. https://doi. } \\
\text { org/10.4102/hts.v77i2.6661 }\end{array}$} \\
\hline \multicolumn{2}{|c|}{$\begin{array}{l}\text { Copyright: } \\
\text { ๔ 2021. The Authors } \\
\text { Licensee: AOSIS. This } \\
\text { is licensed under the } \\
\text { Creative Commons } \\
\text { Attribution License. }\end{array}$} \\
\hline \multicolumn{2}{|l|}{ Read online: } \\
\hline 回的回 & $\begin{array}{l}\text { Scan this QR } \\
\text { code with your } \\
\text { smart phone or } \\
\text { mobile device } \\
\text { to read online. }\end{array}$ \\
\hline
\end{tabular}

Women in Ndau communities, like in many African communities, are the fulcrum of household economies that ensure improved livelihoods of their communities. Thus, they are an indispensable factor in the sustainable development equation of their communities. It is sadly true that women do not own land in most African societies. Consequently, most studies analyse the realities of gender inequality in the distribution of resources that include land. However, very few studies recognise, appreciate and amplify the role of women in reproducing and transforming the society through their participation in agricultural activities even on pieces of land that they do not call their own. In this article we examined the power and influence that women derive from their agricultural activities, especially their association with the cultivation of crops that have often been labelled as feminine. We sought to recognise the agency of women not only in transforming livelihoods, but also gender inequalities in terms of control and influence on the use, valorisation and sale of agricultural produce. We examined the phenomenon of the crops associated with female gender from a new perspective that compels a rereading of the narratives that often dwarf women's agricultural activities and crops associated with them. This article focussed on the production of uninga [sesame] amongst the Ndau of Musikavanthu and Chipinge South Constituencies covering areas that include Rimbi, Manzvire, Mwanyisa, Rimai, Rukangare and Garahwa in south-eastern Zimbabwe. The article's overall theoretical framework is the African women theology that emphasises on African women as agents, not subordinated and passive subjects of history. The study is qualitative, and it used interviews, focus group discussions and observations as instruments for gathering data.

Contribution: The study amplified the transformative role of women in society through their participation in agricultural activities. The findings acknowledged the complementarity of women and men in uninga production in a religio-cultural setting that has often shown biases towards patriarchy. The results are in sync with the reconstructive and liberative motif of the African women theology, which envisage a transformed African society that celebrates gender inclusivity through facilitation of dialogue between the two genders.

Keywords: Ndau women; sustainable development; feminine crops; uninga (sesame); African women theology; African spirituality; gender inequalities; valorisation and sale.

\section{Introduction}

Conventional gender perspectives often depict gender relations in agriculture in southern Africa and beyond in a manner that shows a bias towards men. The portrayal of women is one of subordination and victimhood to the structures of patriarchy. This depiction is too simplistic as it misses the fact that women and men work each in their special way towards the reproduction and transformation of the world in which they live (Vijihuizen 1998). Women in Ndau communities, like in many African communities, are the pivot of household economies that ensure improved livelihoods of their communities. In this article, we explore the agency of women not only in transforming livelihoods but also gender inequalities in terms of control and influence on the acquisition and use of land, valorisation and sale of agricultural produce. Thus, we examine the power and influence that women derive from their agricultural activities, especially their association with the cultivation of small-scale crops. We are aware that women are not a homogenous entity, there are some who are educated and they have the means to navigate the processes of acquiring land. Our focus here is on the Ndau women in the rural areas of the

Note: Special Collection: Women Theologies, sub-edited by Sinenhlanhla S. Chisale (Midlands State University) and Tanya van Wyk (University of Pretoria). 
south-eastern Zimbabwe. We concur with Vijihuizen (1998:1) that, 'women do not only use the land but have a certain measure of control over it'. We look at the phenomenon of the gendered crops from the perspective of African women theology that compels a rereading of the narratives that often dwarf women's agricultural activities and crops associated with them. Some of the gendered small-scale crops include uninga [sesame], mujumbuya [cassava], nyemba [cowpeas], manduwi [groundnuts], nyimo [roundnuts] and many others. We focus on the farming of uninga by the Ndau women seeking to establish how the crop has put women in the forefront in the transformation of the lives of this minority ethnic group. African women theologies proffer muchneeded inspiration to women to surmount all gender challenges to post victory, not only for themselves but also for everyone including their male counterparts. We hold that men also need empowerment by allowing themselves to lose part of the power and privileges assigned to them by patriarchy (Chitando 2010). In many cases, women's resilience and tenacity compel the transformation of toxic gender inequalities for the better. We argue that women have managed on many occasions to lead development-oriented projects especially on the agricultural sector because as mothers, they sustain communities through the mobilisation of their energies for the common good. This echoes the African Agenda 2063 goal number 6 that calls for peopledriven development relying on the potential offered by African people, especially its women and youth (The Africa Union Commission 2015). Thus, women's industriousness and resoluteness remain a source of hope for the attainment of goal number 5 of the Africa Agenda 2063 and goal number 2 of the United Nations' (UN) Sustainable Development Goals (SDGs) that prioritise agricultural productivity and production with a view to reducing hunger, achieving food security and improved nutrition and promoting sustainable agriculture (the United Nations 2015).

\section{Research questions}

- What role do Ndau women play in the allocation and search for pieces of land for farming uninga?

- Do women participate in the valorisation and commercialisation of the produce?

\section{Objectives}

In this study we sought:

- to explore gender dynamics in the allocation and search for pieces of land for the production of uninga.

- to examine the role of women in the valorisation, use and commercialisation of uninga.

\section{Methodology}

We employ a qualitative methodological approach. A qualitative research is based on the inductive research theory that is premised on the constructivist paradigm that treats reality or knowledge as subjective, attainable through interaction with lived experiences of the researched community (Creswell 2003). To this end, we followed an ethnographical research design because our quest is to access the meaning embedded in the Ndau women agricultural practices that are often influenced by the Ndau religio-cultural worldview. We used in-depth interviews, focus group discussions (FGDs) and observations as instruments for gathering data. Participants were selected through purposive and snowball sampling techniques. Purposive sampling is used on two levels. Firstly, we purposively sampled the communities that are into the production of uninga because the crop is not grown in all parts of Chipinge district. Secondly, we purposively sampled the participating households and individual members of the community on the basis of age, gender and required expertise about the production of Uninga. We purposively sampled 15 households (5 households with absent husbands [WAHs], 5 households without husbands and 5 households with husbands), 5 male village heads, 3 female and 2 male elders in the community, 5 young adults ( 3 male and 2 female). Three five-member FGDs were conducted. Focus group discussions comprised same-sex respondents to provide liberating experiences especially for women, by giving them an opportunity to voice their lived experiences. The use of FGDs in this study helped in data triangulation, thereby validating data gathered through other methods. Bloor et al. (2001) are instructive when they assert that focus groups provide an ostensibly attractive medium that requires no technical skills of the group members, and the FGDs can be convened at any and several points in the research process.

The first one was an all-men group, and the second was an all-women group. The third comprised youth of both genders: three female and two male young adults. The five village heads were all male, reflecting the patriarchal nature of the community studied. The rationale for a bigger sample of women participants was two pronged. Firstly, it is a deliberate effort to avoid male bias that the researchers can bring into the research field. Researchers often approach male participants that they deem to be better sources of data than women (Moore 1988). Secondly, traditionally, amongst the Ndau, uninga is a feminised crop as compared with other crops (Muyambo \& Shava 2020). The research sample comprised the people with experiences with the production of uninga. We also employed snowball sampling to get to other people who could potentially participate in or contribute to the study. Data were collected and analysed concurrently by using thematic coding. We had two themes that are: (1) power and influence in the acquisition and land use and (2) decisionmaking process on the valorisation and commercialisation of uninga. We observed all the important ethical norms in qualitative research including informed consent, confidentiality, privacy and anonymity (Sanjari et al. 2014). We also explained why the participants were chosen in the sample and why they were being requested to answer the research questions (Peter 1994). 


\section{Theoretical framework}

We employ Oduyoye's (1990) two-winged African women theology as our lens in traversing power dynamics in the production of uninga, a gendered small-scale crop amongst the Ndau. Oduyoye calls on African Christianity to practise a 'two-winged' theology that emphasises on equal access of both genders to communication with God (Gathogo 2010). Oduyoye's (2001) African woman theology is a call on both women and men to examine African culture with gendered lenses, thereby inviting both of them to create a culture of inclusiveness. Thus, she urges inclusivity as opposed to exclusivity, unity as opposed to division and respect in gender relations. As Gathogo (2010:1) observes, African women's theology is a post-colonial theology, 'that offers a chance to right the African wrongs that are the by-products of patriarchy'. To this end, African women's theology, like African theology of reconstruction, has a reconstructive and liberative motif. For instance, Kanyoro (2006) envisages a transformed African society that celebrates gender inclusivity through facilitation of dialogue between the two genders. We settled on Oduyoye's African women's theology cognisant of the presence of a diversity of women theologies. Although the goal of the diverse women theologies is the same, they operate within different contexts (Phiri 1997). Oduyoye focusses on women in the context of culturally oppressive Africa, which happens to be the locus of our article. The following section deals with a brief socio-economic history of the Ndau to put the Ndau women's uninga production into perspective.

\section{Social and economic history of the Ndau}

The present-day Ndau people live in the vast region that comprises the 'south-eastern parts of Zimbabwe, specifically Chimanimani and Chipinge Districts' of Manicaland Province, sprawling into the central and western parts of Mozambique (Dube 2017:1). Chipinge district has seven Ndau chiefdoms, namely Garahwa, Gwenzi, Mpungu, Mahenye, Mapungwana, Musikavanthu and Mutema. The first six chieftaincies' jurisdictions stride the international border in the same manner that their Mozambican counterparts do, a typical example being chief Macuiana (Portuguese). The research data were gathered in the two chieftaincies of Musikavanthu and Garahwa.

Patricio (2011) and MacGonagle (2007) have shown that for many centuries, the Ndau people have remained undisturbed by the border. They have maintained close links and are united in all spheres of social, economic and political lives to the extent that they are identified as one large community that extends from one country to the other across the international boundary. Patricio (2011) succinctly expresses this situation as follows:

So the Ndau of Mozambique continue to cross the border like they did in the past and go to Zimbabwe to visit their family, to consult healers and traditional authorities, to go to school and to take part in ceremonies. It seems these people do not feel the impact of the international boundary demarcation in the daily lives-not in colonial times, not even today. (p. 678)

Konyana's (2018:55) observation aptly summarises the situation of the Ndau when he says that, '[T]he Ndau people have had uninterrupted de facto dual citizenship status of being Zimbabweans as well as being Mozambicans'.

\section{Ndau family institution}

The Ndau notion of the mphuri [family] is an all-embracing phenomenon expressed through a web of relationships that goes beyond the living beings. It is rather a cosmic totality that includes the living, the living-dead, the unborn, the flora and the fauna and the rest of other inanimate elements comprising the environment (Sipeyiye 2020). As a result, the Ndau respect all forms of the natural resources that include land, rivers, mountains, flora, fauna and many others that can operate as the objects of the manifestation of the spirit world in the human world. Ukama [kinship] is the concept that touches on the family relatedness and communal belonging, which has kept the Ndau family much the same as it was before colonisation (Konyana 2018). The Ndau family is patriarchal. The most senior male member, in most cases the grandfather (baba akuru), is the revered head of the extended or connected family. He is the family leader whose major role is to advise the family on all matters of life and more importantly to connect the family with its ancestral spirits.

\section{Ndau women and economic activities}

Women in the Ndau society are crucial in ensuring a functional society. They are essentially the key holders of traditional food and medicinal practice. Vijihuizen (1998) opined that at the close of the 19th century and the beginning of the 20th century, there was an observable division of labour in the Ndau society. Men were responsible for clearing the land and the provision of security, whereas women took care of food production, distribution, storage and consumption in the home. Women have a strong connection with their natural environment through their link with Mother Nature. The Ndau people have respect and a strong belief that the natural world provides habitat to the spiritual world, and it is the provider of foods, minerals and other resources.

The sacred shrines, wetlands and woodlands are spiritual habitats and the foundation of survival. Their farming activities are very much regulated by a strong belief in the spiritual presence. Their indigenous spirituality inspires a work ethic that promotes a sustainable use of natural resources for sustainable livelihoods. It also regulates their interaction with the natural resources, especially the wetlands.

Agricultural activities are the domains of Ndau women. They prepare and preside over rituals that are intended to safeguard crops from pests and other predators. In the 
Ndau's strictest spiritual sense, some crops such as uninga, groundnuts, roundnuts and mujumbuya [cassava] are feminine and a preserve for the elderly women because of their supposedly ritual purity (Sipeyiye 2020). They are food supplements that matter most especially in times of hunger and starvation. But this does not mean that men do not participate in the farming processes involving the crops mentioned above. They provide complementary services when they are called to do so by their female counterparts, but with a strict adherence to prescribed ritual behaviour. For example, the gathering, collection of organic manure and erection of fences around the fields are men's allotted tasks.

Women therefore determine the social status of the community because they are largely the ones who produce the material wealth as mothers and farmers. Men played the supportive role. It is incorrect, as Bossen (1989) observed about foragers, to apportion the responsibility of food provision to men. She argues that:

[T] he presumed universal role of men as primary providers for the family is a myth, as is the women's presumed dependency. Detailed observations show that women generally do the bulk of the food gathering. (pp. 319-320)

Mukonyora (2007) construes the myth as a colonial construct that sought to destabilise African economic systems. Women in Ndau society have always been pivotal in the provision of food. There is little wonder therefore that even today the domain of agricultural production has remained a predominantly women's space (Vijihuizen 1998).

\section{Findings and discussion}

\section{Women and the allocation and search for, and cultivation of, pieces of land for uninga}

There are a number of dimensions with regard to how women farmers of uninga obtained pieces of land for cultivation. Women in polygamous households with husbands had varying experiences. Five women in polygamous households (WPH) raised the view that they were allocated the pieces of land on which they cultivate uninga when they married into the family. As the family expanded, as male children became of age, the pieces of land were further subdivided creating a huge demand for land. As a result, the women utilised their social networks that include friends at church as well as colleagues in other women social organisations such as mukando [women socio-economic clubs meant for fund generation] to get rented space for the crop. Two WPH said that they first sought for permission from their husbands to search for rented piece of land to avoid friction if it was carried out behind his back. Two WPH said that they just went ahead and procured rented farming space from friends. They had to inform their husbands (kushuma) afterwards. They had no qualms about soliciting for permission first because they argued that they had learnt to be creative for the onus of fending for their children and the husbands rests on them. So if they lack creativity and industriousness, they would also lose out on the love of the husband for they would be outsmarted by other wives in the household. One WPH discussed the need for more land with her husband and agreed to approach an elderly couple who had since retired from working on their vast piece of land.

Five women from monogamous households (WMHs) said that they till the ancestral lands of the household with the help of their children and sometimes with the help of uncles in the extended family who would provide draught power. Two of them had also to look for supplementary pieces of land from their maternal roots across the border with Mozambique. The two stressed that reliance on kinship ties across the border is a very common thing for people in the borderland. Three of the five women in households WAHs said that they use the family land as well as rented pieces of land in the neighbourhood. They convinced their husbands working in South Africa about the lucrative business of sesame production, who had to provide supplementary financial support for rentals. The women had their own savings from the sale of groundnuts and roundnuts. They said that the husbands were supportive because they considered the venture as a window to increase the family earnings for improved livelihoods.

Two other women stressed that they just made an individual decision to suspend the growing of other crops except groundnuts, in the household land, which they put under sesame. Their plan was to use the proceeds from sesame to buy maize grain for household consumption. They had to inform their husbands about the decision later. The husbands were agreeable because the previous season's maize harvest was poor. They shared the view that generally men are not too difficult when it comes to farming issues because most of them were pushed by the frustrations of a series of poor maize yields in recent times to leave home for greener pastures in either South Africa or Botswana.

Three WMHs maintained that they worked together on the family land with their husbands. The husbands are motivated by the commercialisation of the crop, but they lacked the required skills for the task. So the wives, by using their experience with the production of the crop before, oversee and direct every activity on the piece of land. The Ndau women in the furthest corner of Chipinge South in Garahwa, for example, cried foul about their loss of household land to MacDom-ARDA, a joint venture between the government through Agricultural and Rural Development Authority (ARDA) and Green fuel company that is into sugar cane production. The pieces of land they were given as compensation (>0.2 ha) are too small for average households in the area. The compensation processes ignored a number of Ndau family dynamics, for example polygamous households. As a result, a number of households exploited their kinship ties with the Ndau across the border on the Mozambican side to get land for subsistence farming.

From the views of the different categories of women respondents mentioned above, it emerged that in the majority of cases women make individual decisions that are later 
endorsed by their husbands. In a number of cases again, women and men make joint decisions on the acquisition of land for the production of uninga. It is evident from the views of the respondent that women are always on the forefront in the initiative, with the support of their husbands because they shoulder the burden of feeding the family. So, even though Ndau women have historically found it difficult to own rural land in their own right, it can be argued that besides managing activities on the land, they exercise a certain measure of control over land use and strategies on acquiring more land. This is generally the picture that is emerging in the sub-Saharan Africa as confirmed by a GENNOVATE Report on Maize on 27 villages in 7 countries including Zimbabwe that:

Women are increasingly important in agricultural processes. The feminisation of agriculture continues. In 80 percent of the research villages, men's temporary migration is on the rise, and women manage farms in ever higher numbers. In many cases, married women run diverse farming and livestock activities independently and over long periods of time. A significant number of farms are headed by women on their own. (Petesch et al. 2017:iv)

To this end, women' agency in general is not passive, but active and creative. Ndau women are always on the forefront in search of more land for the production of uninga, with the support of their husbands because they shoulder the burden of feeding the family. We concur with Vijihuizen's (1998) that:

We have to look beyond the conventional generalised models of patriarchal families, i.e. women are not passive recipients and victims of patriarchal structures but are strategic social actors who also reproduce, manipulate and transform daily life. (p. 1)

The above quote flies in the face of most feminist works that are bent on women stereotyping without acknowledging that, indeed, women, particularly Ndau women, are the beacons of sustainable development at the community level. They are the unsung heroines for food security evident in their lucrative ventures into uninga production.

The study also established that there is an acute shortage of arable land. The traditional leaders confirmed the shortage of land in their areas of jurisdiction, citing the expansion of households as a result of children becoming of age as well as the loss of farming land to Green Fuel in some affected areas. However, they claimed that they have managed to assist wherever there was need even in those difficult circumstances. They highlighted that the demand for land has come in the wake of the commercialisation of uninga where even the youth of both sexes are lured into farming because of the prospects of getting foreign currency. Before that, households had little problems with land to the extent that some pieces of land had been lying idle for many years. In cases of women and youth who need land, the traditional leaders emphasised that they had to be people from their areas of jurisdiction. They further indicated that women who needed extra land had to have enough evidence that they have sought the consent of their husbands. As for the youth, they require the parents or next of kin to present themselves to the traditional leaders with their request. However, youth from childheaded families are known and helped without the request for usual protocols to be followed. It was also noted that because of increased demand for land, traditional leadership is slowly losing its jurisdiction over land because once land is commercialised like rented land, all sorts of things happen. Traditional leadership complained of the failure by the owners of rented land to honour agricultural rituals such as rain-petitioning ceremonies.

Youth in one FGD that comprised three young adult girls and two young adult boys admitted that there had been a land rush with the commercialisation of uninga. Both girls and boys indicated that they had to be adventurous, going to Mozambique to solicit for land from relatives and nonrelatives exploiting already existing social networks. These views confirm those of Patricio (2011) and MacGonagle (2007) cited earlier in this article that the Ndau have remained undisturbed by the border. They have maintained close links and are united in all spheres of social, economic and political lives.

\section{Women and land preparation and planting}

On the cultivation of the land, the respondents revealed during focus group discussions and interviews that uninga was traditionally grown by women on a small scale by using intercropping method. Until recently, uninga was planted in between a main crop in a good season. The main crop was usually maize, millet, sorghum or beans. The planting was carried out by women during weeding usually in the month of Mushekwa, Ndau name for February (Muyambo \& Shava 2020). The rains would have subsided significantly as compared with November, December and January. Because uninga has become a cash crop, the cultivation method has changed. The intercropping method no longer suffices with its new status. Many households have either looked for more pieces of land or turned their pieces of land that they have already to the exclusive production of uninga. Respondents stated that the land has to be thoroughly tilled and made ready for sowing.

Women in households with cattle or donkeys use animaldrawn ploughs. Those who are without draught power hire for a fee or through barter system. In case of barter system, the women would exchange uninga or groundnut seed for the hired labour. Some women respondents said that they also use Mukote [work party] to till the land. In rare cases, women would use chibhakera [by using traditional hoeing method] to prepare the land. When the piece of land is ready uninga is sown manually by hand. Women mix the small uninga seeds with soil before broadcasting, to ensure an even spacing of the crop. The seed is then covered with light soil by using a tree branch drawn either by animals or humans to ensure a maximum germination rate (Muyambo \& Shava 2020). The crop was said to germinate between five and seven days. The farmer makes some constant checks for pests and 
other predators. They spray pests and predators using Cabral. The respondents also said that they also utilised indigenous pest prevention methods such as the application of ashes to the crop. The participants shared that the crop is weeded at most twice before maturation.

The spirituality associated with uninga as an exclusive female crop has vanished with the commercialisation of the crop. However, it is still women and their children who are mostly involved in land preparation, planting, harvesting and storage of the crop. This is a result of ever-rising migration of men where a larger number of women than men live in the rural villages as Petesch et al. (2017:iv) and Vijihuizen (1998:125) also observed in their separate researches. This also explains why children are always there helping their mothers with land preparation, planting, managing the crops and harvesting. From the views of the respondents, men encourage their women's economic activities to improve household livelihoods. The supportive stance of men points to a crop of empowered men who allow themselves to lose part of the power and privileges assigned to them by patriarchy (Chitando 2010). This goes to show that women and men work each in their special way towards the reproduction and transformation of the world in which they live (Vijihuizen 1998). Joint decision-making and the support of the male gender of the agricultural activities of the female gender meet the focus of the African women theology. It calls on both women and men to examine the African culture with gendered lenses, thereby inviting both of them to create a culture of inclusiveness and respect in gender relations.

\section{Women and harvesting and storage}

Respondents from both individual and FGDs revealed that a brown-yellowish colour of the stem and leaves is a sign of maturation. Once the farmers observe this change in colour, harvesting of the crop begins in earnest. Respondents also averred that the harvesting stage is the most critical stage where the quality of the yield is either consolidated or lost. They recount that labour shortages at this stage may delay harvesting and stacking, resulting in compromised quality (Muyambo \& Shava 2020). Women and their children make the main part of the labour pool. Respondents also said that friends and social acquaintances of the women farmers usually volunteer to assist with harvesting. Some would openly make their intention known that they would want to be paid in form of uninga seed whilst others leave the payment part to the discretion of the host woman farmer. The woman farmer would then work out the payment modalities that are often in the form of seed measures equivalent to labour rendered. The ripe crop is cut, made into bundles and ferried in scotch carts or carried by head to the mbuwa [a cow dung-hardened threshing floor]. The farmers can also use canvases as an alternative to mbuwa to minimise seed loss as well as seed quality loss. Terefe et al. (2012) affirm that canvases are free from various impurities that can reduce the quality of uninga. The respondents stated that shocks were moved every few days to enhance dryness. Women would collect the seed before threshing the remaining shocks with rods to ensure maximum collection of the seed. Women collect and winnow the seed to free it of any dirt before packaging. Winnowing is an exclusive woman expertise so they are hired by male farmers. This is why men would be an awkward presence in most stages of the processing of the sesame crop.

Respondents from face-to-face and focus group discussions emphasised that packaging and storage were important for food security. They stated that the clean seed was stocked in sacks in readiness for both storage and for sale. The elderly informants shared that the seed was traditionally stored in pots, calabashes or nyumbu because the production was on a small scale. Now that it is produced on a larger scale, they emphasise the need to ensure that the seed is as dry as possible right from the mbuwa as it is very small, making it difficult for free air circulation in storage. This resonates with Terefe et al. (2012) who raised the need for the seed to be as dry as possible before storage with a moisture content of below 7\%. It was also noted that the stored seed requires some periodical checks for pests. On a positive note, respondents averred that unlike other crops, uninga is not easily susceptible to pests. Nevertheless, they emphasised regular cleaning of storage areas and removal of any substances that produce undesirable smells to avoid the loss of the aroma of the seed. The farmers constantly inspect the warehouse to check for any damages by insects or dampness of the room and taking appropriate measures to solve the identified problem. The respondents recounted that under excellent storage conditions, uninga can be stored for one year.

\section{Women and the valorisation, use and commercialisation of uninga}

Respondents unanimously admitted that the production of uninga has huge socio-economic significance as it had transformed their lives for the better. They were realising foreign currency in the form of the United States Dollars and South African Rand from selling uninga. During the time when the data were gathered, they were selling a kilogram of uninga for between R10 and R20 or US\$1. The market price, although not very attractive by international standards, meant a fortune to some households, which realised annual produce of around $1000 \mathrm{~kg}$ of uninga. The major market for the farmers' produce is buyers from the neighbouring Mozambique. The buyers came into the farming communities, purchasing uninga from households. So in most cases it is these buyers who determine the price. However, because of COVID-19-induced lockdown regulations, there mushroomed some middlemen who lowered the rate to between R8 and R16 per kilogram. As a result, many women farmers cried foul, some women respondents said that they were not usually in a hurry but would be patient until uninga selling price was favourable unlike men who accepted any offer to buy beer. The women farmers would either bargain for a higher rate or weigh the benefits between selling their produce to these buyers and 
exchanging it with maize grain. They said that when exchanging with maize grain, one kilogram of uninga is equivalent to four kilograms of maize grain. This means that a $5 \mathrm{~kg}$ measure is equivalent to a $20 \mathrm{~kg}$ bucket of maize grain. Maize grain is going for between US\$5 and US\$6. Using this exchange formula they still realise the original price offered by the Mozambican buyers before the middlemen emerged.

Women bargain for a fair price of their produce. This means that besides cultivating uninga, they are also involved in giving their agricultural produce a value. They contribute to constructing the markets through negotiating prices, withholding their produce in the event of poor offers on the market and weigh better paying options of disposing their produce. More importantly, in the valorisation of their produce, they are not entirely guided by economic considerations. Rather, some produce would be shared with friends who would have assisted in one way or another in the whole production process. So they are meticulous in issues to do with who gets what measure for what reason even though the gesture is done under the guise of extending gifts to social acquaintances. It is the value of kinship that the Ndau cherish that is at play. We can argue that Ndau women's valorisation of uninga should not only be understood entirely in economic sense, it also carries a huge social value. It creates $u k a m a, \mathrm{a}$ social capital that makes the Ndau society cohere. This creates formidable social networks resulting in coexistence, harmony and cooperation. This is a practical way of expressing $u b u n t u$, with women as the torchbearers. So in all these transactions, women are firmly and steadily in control.

The elderly women highlighted the socio-economic benefits that the Ndau community realised in the old days from uninga. The crop conferred some social status on women. They revealed that growing uninga in their fields and excellent preparation of $u n d u$ as both oil and flavour to relish would separate wise women from the foolish and lazy ones. Uninga, as nthikiti [relish flavour], is a delicacy amongst the Ndau. The elderly women derived great pride and joy in preparing the dish. Respondents also shared that $u n d u$ also served as an indigenous baby-weaning formula, underlining its nutritional and spiritual value (Muyambo \& Shava 2020). Once the baby partook of $u n d u$, he or she would not think of breastfeed, but water throughout the day.

Overall, what emerged from the field data in respect of the theme of the role of Ndau women in the allocation and search for pieces of land for farming uninga is that there are indeed skewed gender land ownership patterns amongst the Ndau producers of uninga. This scenario is attributed to, amongst other things, the general patriarchal culture which limits women's access to property ownership. Nevertheless, women are not passive victims of the patriarchal structure. They have manipulated their usufruct rights through marriage to have access to land and utilise it to the maximum to realise high uninga produce that has transformed livelihoods. Those women with husbands have also influenced some joint decision-making processes with their spouses in their search of rented space. Even widows have skilfully exploited their patrilineal kin to mobilise resources and support to 'own' and work on household land. There were also indicators that men are showing signs of empowerment where they are shunning a rigid culture that would always find it offensive for women to initiate and execute decisions on matters of getting a space for farming. This is attributed to the emergence of more fluid gender norms that give leeway to women to move about utilising their social networks to solicit for more land.

Gender relations are not static. We agree with Petesch et al. (2017:34) that, 'both women and men have interests in maintaining some cherished norms, even as they withdraw from others'. Women in this regard, strategically withdraw from norms that 'regulate their physical mobility and social interactions beyond their household even as they conform to other norms that require their submission and domesticity' (Petesch et al. 2017:34). Men may also desire to withdraw from their masculine expectations assigned by patriarchy, especially when the task of providing and speaking for the family becomes a daunting task. The positive transformation of gender relations in the context of uninga production is generally partly owed to a rise in men's migration that makes it impossible for them to be always in control. It is also attributable to the realisation that more often than not, women have an edge above men in entrepreneurial initiatives (Petesch et al. 2017).

With regard to the theme of giving value, use and sale of uninga, men have become supportive of the agency of women not only in transforming livelihoods but also gender inequalities in terms of control and influence on the use, valorisation and sale of uninga. What has to be noted also is that the cultivation, processing and preservation of the crop are arduous and demand some skills and patience that men do not normally have. Men would make a very awkward presence in the feminine space at every stage. Women generally embrace an inclusive decision-making process, bringing on board their husbands, in giving value to their agricultural produce, but in most cases, they make decisions on their own and inform later. They are the ones who decide the amount of the produce to be allotted to their social networks, to sell or to consume. Thus, emphasis should not be centred only on how women work on the fields, rather it should also be on how they shape the value of their produce. So women certainly do not work for nothing as conventional gender theories often purport (Vijihuizen 1998).

\section{Conclusion}

The article has demonstrated that uninga is predominantly a female crop. Women are the producers of the crop; they are at the thick of things from land acquisition, tillage, planting, weeding, harvesting, storing to selling the crop. The article acknowledges the complementarity of men and women in uninga production, in a religio-cultural setting that has often shown biases towards patriarchy, contrary to conventional feminist scholars who portray men as perpetrators of women 
marginalisation and underrepresentation. The article has shown that Ndau women are decision-makers right from the beginning of uninga production up to its marketing. The study has amplified the transformative role of women in society through their participation in agricultural activities. The findings are in sync with the reconstructive and liberative motif of the African women theology, which envisages a transformed African society that celebrates gender inclusivity through facilitation of dialogue between the two genders.

\section{Acknowledgements}

The authors would like to express their gratitude to all the participants in the interviews during the data collection process. None of the participants gave consent to have their names mentioned.

\section{Competing interests}

The authors declare that they have no financial or personal relationships that may have inappropriately influenced them in writing this article.

\section{Authors' contributions}

M.S. was responsible for the conceptualisation of the research question/problem that the article addresses, formal analysis, visualisation of the expected research outputs and outcomes, writing of the original draft and managing and supervising the whole research process. T.M. did the methodology and research design, reviewed and edited the draft. Both authors jointly carried out the investigation of the problem through conducting fieldwork and the validation of the research data. They also jointly met the research costs from their personal coffers.

\section{Ethical considerations}

Ethical clearance to undertake the research was granted by the Faculty of Arts Research Ethics Committee of the Midlands State University $(001 / 21)$.

\section{Funding information}

The research received no specific grant from any funding agency in the public, commercial or not-for-profit sector.

\section{Data availability}

The authors accessed the following web links for publicly available datasets: https://www.un.org/en/africa/osaa/ pdf/au/agenda2063-first 10yearimplementation.pdf, https:/ / sustatinabledevelopment.un.org/?menu=1300.

\section{Disclaimer}

The views and opinions expressed in this article are those of the authors and do not necessarily reflect the official policy or position of any affiliated agency of the authors.

\section{References}

Bloor, M., Frankland, J., Thomas, M. \& Robson, K., 2001, Focus groups in social research, SAGE, London.

Bossen, L., 1989, 'Women and economic institutions', in S. Planner (ed.), Economic anthropology, pp. 318-350, Stanford University Press, Stanford, CA.

Chitando, E., 2010, “'One Man Can": Gideon Byamugisha and redemptive masculinity', BOLESWA: Journal of Theology, Religion and Philosophy (BJTRP) 3(2), 46-62.

Creswell, J.W., 2003, Research design: Qualitative, quantitative and mixed methods approaches, SAGE, London.

Dube, E.E.N., 2017, 'Getting married twice: The relationship between indigenous and Christian marriages among the Ndau of the Chimanimani area of Zimbabwe', PhD thesis, University of South Africa.

Gathogo, J., 2010, 'Mercy Oduyoye as the Mother of African Women's Theology', The Journal, Thelogia Viatorum: Journal of Theology and Religion in Africa 34(1), 1-18.

Kanyoro, M., 2006, 'Beads and strands: Threading more beads in the story of the circle', in I.A. Phiri \& S. Nadar (eds.), African women, religion, and health: Essays in honour of Mercy Amba Ewudziwa Oduyoye, pp. 19-42, Orbis, Maryknoll, NY.

Konyana, E., 2018, 'When culture and the law meet: An ethical analysis of the interplay between the Domestic Violence Act and the traditional beliefs and cultural practices of the Ndau people in Zimbabwe', DPhil thesis submitted to the School practices of the Ndau people in Zimbabwe', DPhil the
Philosophy and Classics, University of KwaZulu-Natal.

MacGonagle, E., 2007, Crafting identity in Zimbabwe and Mozambique, University of Rochester Press, Rochester.

Moore, H.L., 1988, Feminism and anthropology, Polity Press, Cambridge.

Mukonyora, I., 2007, Wandering a gendered wilderness: Suffering and healing in an African initiated church, Peter Lang, Oxford.

Muyambo, T. \& Shava, S., 2020, 'Indigenous crop production for sustainable livelihoods: A case of uninga in the rural areas of South-Eastern Zimbabwe', International Journal of Community Well-Being. https://doi.org/10.1007/s42413020-00102-6

Oduyoye, M.A., 1990, 'The search for a two-winged theology: Women's participation in the development of theology in Africa', in M.A. Oduyoye \& R.A. Kanyoro (eds.), Talitha, qumi!: Proceedings of the Convocation of African Women Theologians, Trinity College, Legon-Accra, Story by Mercy Amba Oduyoye and Musimb Kanyoro, Daystar Press, Ibadan, 24 September - 02 October 1989, pp. 31-56.

Oduyoye, M.A., 2001, Introductions in feminist theology: Introducing African Women's Theology, Sheffield Academic Press, Sheffield.

Patricio, M., 2011, 'Ndau identity in Mozambique-Zimbabwe Borderland', Internationa Organization 43(94), 673-692.

Peter, C.B., 1994, A guide to academic writing, Zapf Chancery, Eldoret.

Petesch, P., Badstue, L., Williams, G., Farnworth, C. \& Umantseva, A., 2017, Gender and innovation processes in maize-based systems, GENNOVATE Report to the CGIAR Research Program on Maize, GENNOVATE Research Paper, CIMMYT, Mexico, DF.

Phiri, I.A., 1997, 'Doing theology in community: The case of African women theologians in the 1990's', Journal of Theology for Southern Africa 99, 68-76.

Sanjari, M., Bahramnezhad, F., Fomani, F.K., Shoghi, M. \& Cheraghi, M.A., 2014, 'Ethical challenges of research in qualitative studies: The necessity to develop a specific guide', Journal of Medical Ethics and History of Medicine 7(14), 1-10.

Sipeyiye, M., 2020, 'Rethinking environmental sustainability thropugh the Ndau notion of communal existence', in N. Penxa-Matholeni, G.K., Boateng \& M. Manyonganise (eds.), Mother Earth, Mother Africa: African Indigenous Religions, pp. 85-105, African Sun Media, Stellenbosch.

Terefe, G., Wakjira, A., Berhe, M. \&Tadesse, H., 2012, Sesame production manual, Embassy of the Kingdom of the Netherlands, pp. 1-46, s.I.

The African Union Commission, 2015, Agenda 2063, The Africa we want: A shared strategic framework for inclusive growth and sustainable development: First Ten- Year Implementation Plan 2014-2023, September 2015, viewed 10 March 2021, from https://www.un.org/en/africa/osaa/pdf/au/agenda2063first10yearimplementation.pdf.

United Nations, 2015, United Nations Development Goals 2030, viewed 08 March 2021, from https://sustatinabledevelopment.un.org/?menu=1300.

Vijihuizen, C., 1988, “"The people you live with" gender identities and social practices, beliefs and power in the livelihoods of Ndau women and men in a village with an irrigation scheme in Zimbabwe', PhD thesis, Wageningen. 